NOTE

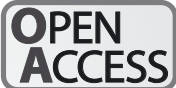

\title{
Interspecific differences in depth preference: regulation of larval transport in an upwelling system
}

\author{
Seth H. Miller ${ }^{1, *}$, Steven G. Morgan ${ }^{1,2}$ \\ ${ }^{1}$ Bodega Marine Laboratory, University of California Davis, Bodega Bay, California 94923, USA \\ ${ }^{2}$ Department of Environmental Science and Policy, University of California Davis, Davis, California 95616, USA
}

\begin{abstract}
Dispersal is fundamental to understanding the ecology and evolution of species and effectively managing resources, but information on dispersal is rare for the vast majority of marine life that develops as miniscule larvae in the plankton. Until recent evidence to the contrary, it was widely suspected that larvae developing in productive upwelling regimes along eastern ocean margins are susceptible to cross-shelf transport by strong, dynamic currents and often are unable to replenish populations. We now show that interspecific differences in depth preference likely play a role in regulating differences in offshore migration from adult populations. Two open-coast species (Petrolisthes cinctipes and Pachygrapsus crassipes) did not undertake endogenously timed tidal vertical migrations but an estuarine species (Hemigrapsus oregonensis) did, which would facilitate seaward dispersal. Surprisingly, none of the 3 species undertook diel vertical migrations in the laboratory, even though all do in the field. Diel vertical migrations in marine and freshwater species elsewhere in the world are cued by light and reduce fish predation, but they may be cued by turbulence in upwelling regimes, thereby reducing transport from adult populations. Thus, larvae of species that hatch in different locations and develop at different distances from the shore exhibit diverse larval swimming behaviors that regulate transport in dynamic upwelling regimes in previously undescribed ways, which has implications for population connectivity, local adaptation and resource management.
\end{abstract}

KEY WORDS: Dispersal $\cdot$ Vertical migration $\cdot$ Larval retention $\cdot$ Ekman transport

\section{INTRODUCTION}

Information on dispersal is essential yet unknown for typical marine organisms, resulting in longrunning debates about how far tiny larvae disperse and the degree of behavioral control over their movements in a dynamic ocean. Until recently, it was widely believed that larvae had little control over their transport in coastal upwelling regions along the western margins of continents. In upwelling regimes, prevailing winds combine with the Coriolis effect to generate rapid offshore transport of surface waters (Ekman transport), which in turn draws nutrient-rich bottom waters to the sur- face nearshore. We now know that larvae of nearshore species reliably migrate different distances offshore before returning nearshore to replenish adult populations in upwelling regions (Morgan et al. 2009a, Shanks \& Shearman 2009, Morgan \& Fisher 2010).

Characteristic circulation of upwelling regions enables zooplankton to limit cross-shelf and alongshore transport by regulating depth in opposing stratified currents (Morgan et al. 2009b, Morgan \& Fisher 2010). Some species remain close to shore throughout their planktonic duration by remaining below a shallow Ekman layer (depth preference) or only rising into productive surface waters to for- 
age at night when winds relax and offshore flow is weaker than during the day (diel vertical migration; Rosenfeld 1988). Other species migrate farther onto the shelf by remaining in the Ekman layer early in development and returning onshore by moving deeper in the water column late in development (ontogenetic vertical migration; Pillar et al. 1989); the same process could affect the alongshore transport of larvae if alongshore currents are moving in different directions at different depths. In addition, the extent of cross-shelf transport in estuaries and nearshore embayments, where tides are usually strongest, may differ between species and be modified by timing ascents and descents in the water column to the tidal cycle (tidal vertical migrations; Cronin \& Forward 1979, Zeng \& Naylor 1996a, Morgan \& Anastasia 2008).

Although larval surveys have identified potential behaviors that may regulate transport in upwelling systems, the proposed behaviors have yet to be documented in the laboratory. Elsewhere in the world, depth preferences are cued primarily by light and hydrostatic pressure and can be modified by other abiotic (e.g. temperature, salinity and turbulence) and biotic factors (e.g. food and predators; Young 1995, Queiroga \& Blanton 2004). Tidal vertical migrations can be timed exogenously or endogenously by cues that oscillate over the tidal cycle (e.g. salinity and temperature), whereas diel vertical migrations typically are cued exogenously by daylight (Zeng \& Naylor 1996b, Lopez-Duarte 2008, Morgan \& Anastasia 2008).

We determined the depth preferences of $3 \mathrm{crab}$ species that live in the upwelling system along the Pacific coast of the USA. Species were chosen to represent diverse life histories to more closely examine the role of larval behavior in regulating larval transport from estuaries or the open coast to nearshore and offshore waters (Lough 1974, Morgan et al. 2009a,b). We determined whether (1) depth preferences differed for the 3 species, (2) larvae undertook tidal or diel vertical migrations and (3) vertical migrations were timed endogenously or exogenously. The porcelain crab Petrolisthes cinctipes lives on the open coast, develops nearshore and has 2 larval stages. The lined shore crab Pachygrapsus crassipes lives on the open coast and in lower estuaries, and larvae develop offshore while molting through 5 stages. The yellow shore crab Hemigrapsus oregonensis lives in estuaries, also develops offshore and has 5 larval stages. Throughout the paper we will refer to species only by their genus name for simplicity.

\section{METHODS}

We collected ovigerous females of Pachygrapsus and Petrolisthes at Bodega Harbor, California, USA, and Hemigrapsus at Stege Marsh, San Francisco Bay, California, USA, during the peak reproductive season in summer 2006. Pachygrapsus and Petrolisthes females were kept in individual cages in the field to maintain natural tidal rhythms until hatching, while Hemigrapsus females were kept in simulated tidal conditions in the laboratory. Crabs were held for no longer than $5 \mathrm{~d}$ and were checked daily for larval release.

Newly hatched larvae from each mother were transferred to separate seawater-filled acrylic columns $(180 \mathrm{~cm}$ height $\times 7.5 \mathrm{~cm}$ diameter $)$. To determine whether vertical migrations were timed endogenously, 5 trials with Petrolisthes and 2 trials with Pachygrapsus were conducted entirely in the dark. To determine whether vertical migrations were cued exogenously by light, 6 trials with Petrolisthes, 7 trials with Pachygrapsus and 4 trials with Hemigrapsus were conducted in a simulated, ambient diel cycle (photoperiod of $14 \mathrm{~h}$ light:10 h dark), with overhead diffuse light (Sulkin 1975). Trials in the diel cycle were conducted for $48 \mathrm{~h}$, and those in the dark were conducted for $27 \mathrm{~h}$.

Due to differences in larval size of the 3 species, 25 Petrolisthes, 250 Pachygrapsus or 250 Hemigrapsus were used in each trial. Each column was demarcated using a permanent marker into eighteen $10 \mathrm{~cm}$ sections, and larvae in every other section were counted every $3 \mathrm{~h}$ for the duration of the trial. Counts in the dark were taken using a flashlight quickly enough that larvae within the column could not respond to the light. Columns were kept in temperature-controlled rooms at typical ambient seawater temperature $\left(11^{\circ} \mathrm{C}\right)$, and had no aeration or seawater input during the trials. Larvae were given $1 \mathrm{~h}$ to acclimate to the columns before the experiment began, and were not fed. All 3 species could easily swim the entire length of the water column in several minutes as newly hatched larvae, and larvae were observed at the end of each trial to ensure they were still alive and capable of swimming.

To determine a weighted mean larval depth (the larval center of mass) at each time period in each column, we binned larvae by depth. Each column section was assigned a depth, which ranged from 20 to $180 \mathrm{~cm}$ for the top and bottom sections, respectively. The overall mean larval center of mass was calculated by multiplying larval counts from each section by the section depth, summing them and dividing by 
the total number of larvae counted. The main limitation of this method is that a column where all larvae occurred at the middle depth would have the same larval center of mass as a column in which larvae were equally distributed. To avoid this problem, we carefully reviewed each trial to ensure that larval centers of mass accurately reflected the location in the column where most larvae occurred.

We used repeated-measures ANOVA (RM-ANOVA) followed by contrast tests to determine whether the mean larval depths differed among the 3 species (Petrolisthes, Pachygrapsus, Hemigrapsus) in a diel cycle and a $t$-test to determine whether mean depths differed between the 2 species (Petrolisthes, Pachygrapsus) in darkness. We report a Welch's pvalue when data sets had unequal variances.

We used $t$-tests to determine whether larvae of each species undertook endogenous tidal vertical migrations by comparing mean larval depths with the tidal stage (flood or ebb) larvae would have experienced at their natal site. Likewise, we compared mean larval depths between trials conducted in darkness and those conducted in a diel cycle to determine whether swimming behavior was endogenous or cued exogenously. Finally, we checked for diel vertical migrations in larvae by comparing mean larval depths between light and dark periods during our diel cycle trials. All statistical analyses were conducted using the JMP 9 statistical software package (SAS Institute).

\section{RESULTS}

Across light treatments and regardless of tidal stage, larvae of $\mathrm{He}$ migrapsus occurred slightly higher in the water column than larvae of Pachygrapsus, which in turn occurred higher in the water column than Petrolisthes. Mean larval depths across all diel cycle trials were significantly deeper (RM-ANOVA, $F=$
154.64, df $=2, \mathrm{p}<0.0001$; Fig. 1) for Petrolisthes $(159 \pm 2 \mathrm{~cm})$ than for Hemigrapsus $(46 \pm 2 \mathrm{~cm})$ and Pachygrapsus $(60 \pm 1 \mathrm{~cm})$; the latter 2 were nearly significantly different in depth from each other $(\mathrm{p}$ $=0.0666)$. Petrolisthes larvae in constant darkness

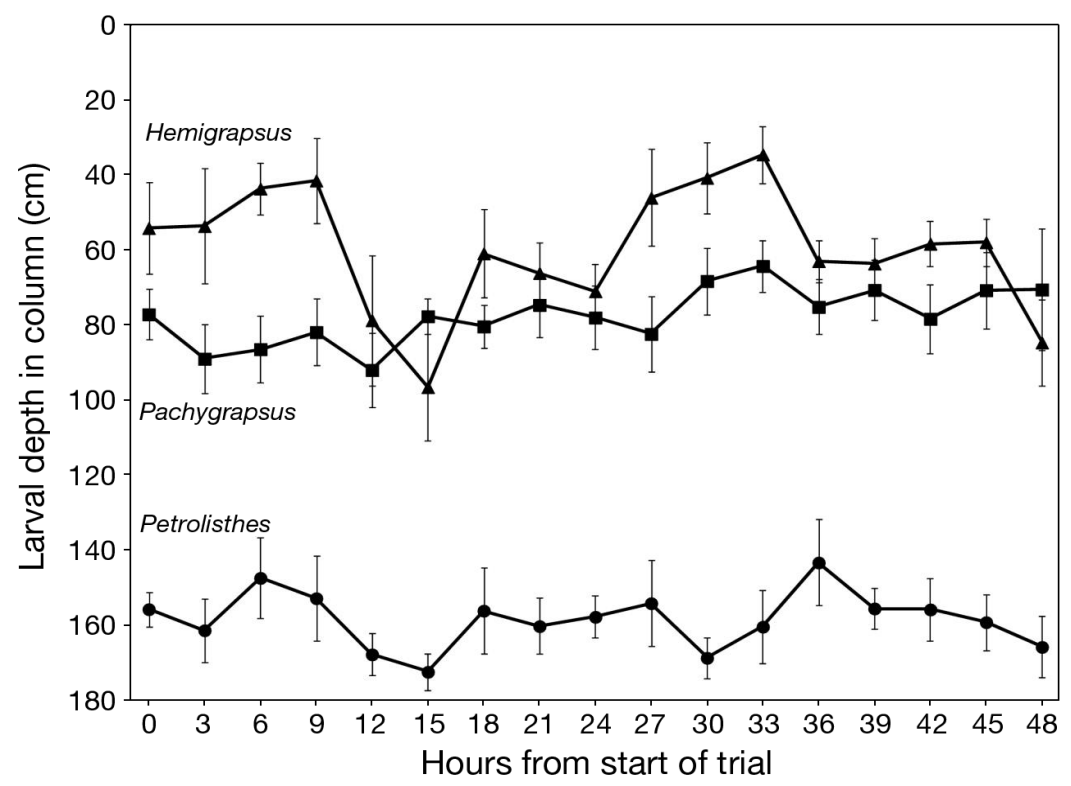

Fig. 1. Mean $( \pm \mathrm{SE})$ larval depths for trials conducted in a $14 \mathrm{~h}$ light:10 h dark diel cycle for Hemigrapsus oregonensis $(\mathrm{n}=4)$, Pachygrapsus crassipes $(\mathrm{n}=7)$ and Petrolisthes cinctipes $(\mathrm{n}=6)$. Trials within species were started at different times on different days due to equipment limitations, so tide and light cannot be shown on this figure

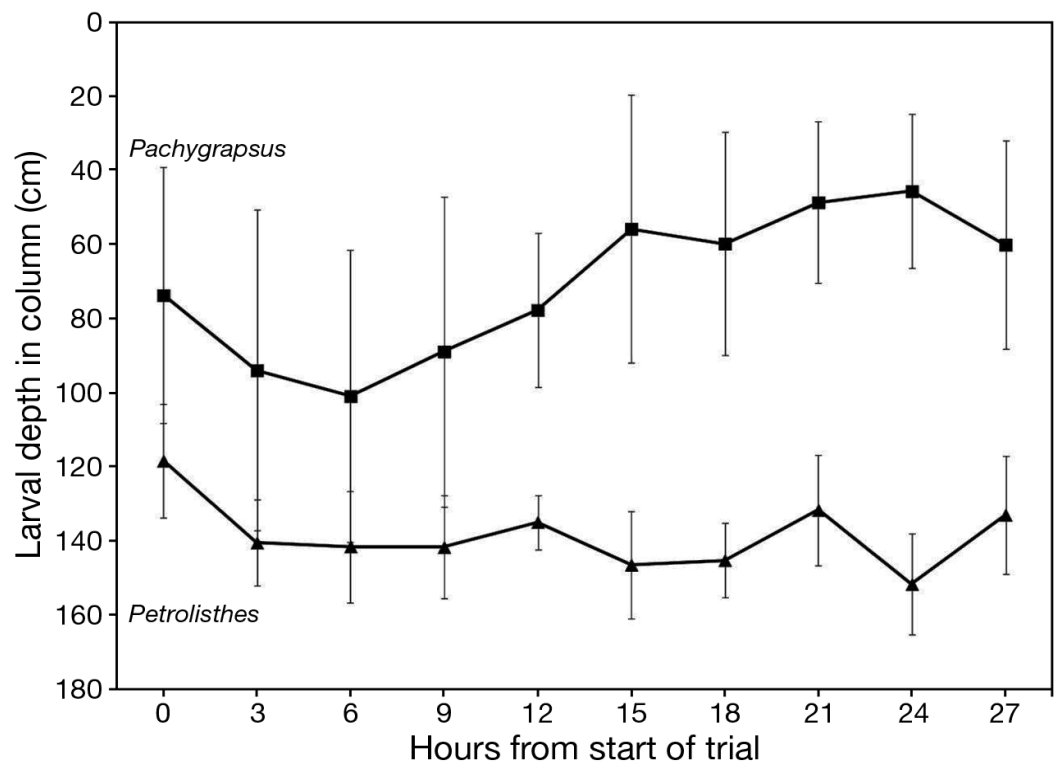

Fig. 2. Mean $( \pm \mathrm{SE}$ ) larval depths for trials conducted in constant darkness with Pachygrapsus crassipes $(\mathrm{n}=2)$ and Petrolisthes cinctipes $(\mathrm{n}=5)$. Trials were started at different times on different days, so tide and light cannot be shown on this figure 
also stayed significantly deeper (119 $\pm 5 \mathrm{~cm}$; Welch's p $<0.0001$; Fig. 2) than Pachygrapsus larvae $(59 \pm 5 \mathrm{~cm})$.

The mean larval depth differed between trials conducted in a diel cycle and those conducted in constant darkness for one of the 2 species that were observed in both conditions (Fig. 3A). Petrolisthes larvae in total darkness occurred higher in the water column than they did in the diel cycle (Welch's p < 0.0001), but Pachygrapsus larvae did not (Welch's p = 0.4255). Diel vertical migrations were not evident for any of the 3 species in a diel cycle (Petrolisthes, $\mathrm{p}=$ 0.4364; Pachygrapsus, Welch's p $=0.3125$; Hemigrapsus, $\mathrm{p}=0.4461$; Fig. 3B) or in constant darkness (not shown; Petrolisthes, $\mathrm{p}=0.3790$; Pachygrapsus, $\mathrm{p}=0.7981$ ).

Neither species from trials in constant darkness undertook endogenous tidal vertical migrations (Petrolisthes, $\mathrm{p}=0.3606 ;$ Pachygrapsus, $\mathrm{p}=0.9072$; Fig. 3C). Only Hemigrapsus undertook tidal vertical migrations in the diel cycle, occurring higher in the column during ebb tides than flood tides (Hemigrapsus, $\mathrm{p}=0.0028$; Petrolisthes, $\mathrm{p}=0.4136$; Pachygrapsus, $\mathrm{p}=0.3309$; Fig. 3D).

\section{DISCUSSION}

Interspecific depth preferences and swimming behaviors documented in the laboratory match those determined in the plankton, where first-stage Hemigrapsus and Pachygrapsus larvae are found only in surface waters, while Petrolisthes larvae are found primarily at depth (Lough 1974, Morgan et al. 2009b, Morgan \& Fisher 2010). The observed behaviors of all 3 species provide further evidence that depth preferences of larvae could regulate the extent of cross-shelf migrations in upwelling regimes. Hemigrapsus and Pachygrapsus larvae are transported to the middle of the continental shelf by swimming into seaward-flowing surface waters (the Ekman layer) during the peak upwelling season. In contrast, Petrolisthes larvae maintain their position nearshore by remaining at depth, where flow can be weaker and often directed onshore (Lentz \& Chapman 1989, Largier et al. 1993, Shanks 2009). Additionally, Petrolisthes larvae were observed to continue swimming downwards upon reaching the bottom of the column during our trials, suggesting they had not yet reached their desired depth, where they would be
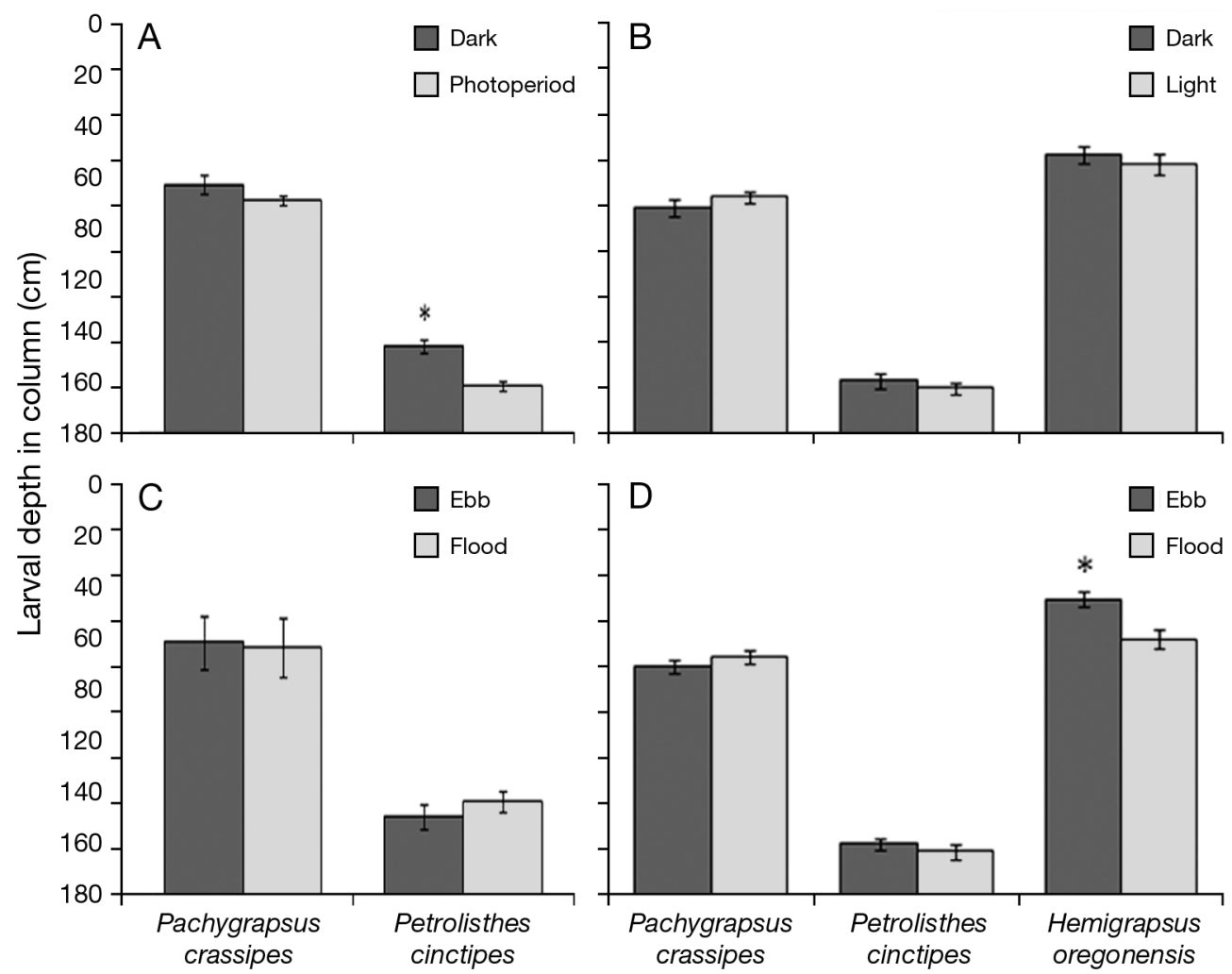

Fig. 3. Comparisons of mean $( \pm \mathrm{SE})$ larval depths between (A) dark and diel cycle trials, (B) dark and light periods during diel cycle trials, and periods of ebb and flood tides during (C) dark and (D) diel cycle trials. Asterisks denote significant differences $(\mathrm{p}<0.05)$ 
found in the field (Morgan et al. 2009b). Laboratory trials using a taller water column or a pressure chamber would be necessary to definitively determine their depth preferences in the laboratory (Huebert 2008). The maintenance of these relative positions in both darkness and light indicates that these swimming patterns reflect endogenous depth preferences that are likely cued by hydrostatic pressure or gravity (Sulkin 1984, Forward \& Buswell 1989).

Interestingly, diel vertical migrations were not undertaken for any species in the laboratory, though all 3 study species undertake diel vertical migrations in the field (Morgan \& Fisher 2010). In addition to the possibility that our light source did not accurately reflect light conditions in the field (Forward 1985, Cohen \& Forward 2009), diel vertical migrations in the plankton could be initiated by exogenous cues that were absent in the laboratory, such as food and turbulence. Nearshore winds in our region typically weaken at night, resulting in a corresponding weakening of surface currents (Rosenfeld 1988). This enables larvae and other nearshore zooplankters to forage in productive surface waters at night at reduced risk of being transported seaward (Batchelder et al. 2002, Woodson et al. 2007), indicating that minimizing seaward transport could be a stronger selective agent in upwelling regimes for diel vertical migrations than reducing predation by visually feeding planktivorous fishes.

Larvae of the estuarine species in our study, Hemigrapsus, appeared to undertake reverse tidal vertical migrations, occurring higher in the water column during ebb tides than flood tides, while the open coast species did not (Fig. 3D). Cues that are more pronounced over the tidal cycle in estuaries, such as salinity and temperature, may select more strongly for tidal vertical migrations in estuarine larvae, including those of many Atlantic species (e.g. Tankersley et al. 1995, Carr et al. 2004, Lopez-Duarte 2008).

Interspecific differences in larval behaviors regulating cross-shelf transport in upwelling regimes may have evolved in response to a gradient in predation by planktivorous fishes, which favors the seaward transport of small, poorly defended larvae with long development times while large, well-defended larvae with shorter development times can survive nearshore (Morgan 1987, 1989, 1990, Hovel \& Morgan 1997, Morgan \& Anastasia 2008). The life-history traits of our study species are consistent with these patterns of cross-shelf transport: the mid-shelf developers (Pachygrapsus and Hemigrapsus) are small, have short spines and complete 5 larval stages, whereas the nearshore developer (Petrolisthes) is large, with long spines and only 2 larval stages. Alternatively, selective forces that could favor seaward transport in upwelling regimes include faster development times in warmer offshore waters, less predation and competition for food by benthic suspension feeders, and access to additional food resources as primary productivity increases in nutrient-rich upwelled waters moving away from the coast.

In conclusion, we have demonstrated that larvae hatched on the open coast in upwelling regions regulate depth in the water column. The species in our study that develop offshore swam towards the surface, which would speed seaward transport during the peak upwelling season when Ekman transport is strongest. In contrast, larvae of the species in our study that develops nearshore descended deep in the water column, where they would be exposed to onshore transport in currents near the seafloor. We also provide the first evidence that a stimulus other than light (e.g. pressure or turbulence) may cue diel vertical migrations in upwelling regimes, as larvae in the laboratory did not migrate on a diel cycle when presented with light cues. Our results suggest the presence of a mechanism that helps explain the vertical and cross-shelf distributions of larvae found in the field, thus shedding light on larval transport and population connectivity in these dynamic, turbulent conditions.

Acknowledgements. We thank C. Lord and J. Fisher for help with field collections and J. W. White, T. Hill, J. Largier and C. Lord for their useful comments on the manuscript. This research was funded by California Sea Grant (NA08AR 4170669) and the National Science Foundation (OCE0326110). This publication is a contribution of the Bodega Marine Laboratory, University of California at Davis.

\section{LITERATURE CITED}

Batchelder HP, Edwards CA, Powell TM (2002) Individualbased models of copepod populations in coastal upwelling regions: implications of physiologically and environmentally influenced diel vertical migration on demographic success and nearshore retention. Prog Oceanogr 53:307-333

Carr SD, Tankersley RA, Hench JL, Forward RB Jr, Luettich RA Jr (2004) Movement patterns and trajectories of ovigerous blue crabs Callinectes sapidus during the spawning migration. Estuar Coast Shelf Sci 60:567-579

> Cohen JH, Forward RB Jr (2009) Zooplankton diel vertical migration-a review of proximate control. Oceanogr Mar Biol Annu Rev 47:77-110

> Cronin TW, Forward RB (1979) Tidal vertical migration: an endogenous rhythm in estuarine crab larvae. Science 205:1020-1022 
Forward RB Jr (1985) Behavioral responses of larvae of the crab Rhithropanopeus harrisii (Brachyura: Xanthidae) during diel vertical migration. Mar Biol 90:9-18

Forward RB Jr, Buswell CU (1989) A comparative study of behavioural responses of larval decapod crustaceans to light and pressure. Mar Behav Physiol 16:43-56

Hovel KA, Morgan SG (1997) Planktivory as a selective force for reproductive synchrony and larval migration. Mar Ecol Prog Ser 157:79-95

Huebert KB (2008) Barokinesis and depth regulation by pelagic coral reef fish larvae. Mar Ecol Prog Ser 367: 261-269

Largier JL, Magnell BA, Winant CD (1993) Subtidal circulation over the northern California shelf. J Geophys Res 98: 18147-18179

Lentz SJ, Chapman DC (1989) Seasonal differences in the current and temperature variability over the northern California shelf during the Coastal Ocean Dynamics Experiment. J Geophys Res 94:12571-12592

Lopez-Duarte PC (2008) Selective tidal-stream transport behavior of fiddler crab (Uca spp.) larvae: comparisons among species and different tidal regimes. PhD thesis, Florida Institute of Technology, Melbourne, FL

Lough R (1974) Dynamics of crab larvae (Anomura, Brachyura) off the central Oregon coast, 1969-1971. PhD thesis, Oregon State University, Corvallis, OR

Morgan SG (1987) Morphological and behavioral antipredatory adaptations of decapod zoeae. Oecologia 73: 393-400

> Morgan SG (1989) Adaptive significance of spination in estuarine crab zoeae. Ecology 70:464-482

Morgan SG (1990) Impact of planktivorous fishes on dispersal, hatching, and morphology of estuarine crab larvae. Ecology 71:1639-1652

Morgan SG, Anastasia JR (2008) Behavioral tradeoff in estuarine larvae favors seaward migration over minimizing visibility to predators. Proc Natl Acad Sci USA 105: 222-227

Morgan SG, Fisher JL (2010) Larval behavior regulates nearshore retention and offshore migration in an upwelling shadow and along the open coast. Mar Ecol Prog Ser 404:109-126

Morgan SG, Fisher JL, Mace AJ (2009a) Larval recruitment in a region of strong, persistent upwelling and recruitment limitation. Mar Ecol Prog Ser 394:79-99

Editorial responsibility: Hans Heinrich Janssen, Oldendorf/Luhe, Germany
Morgan SG, Fisher JL, Miller SH, McAfee ST, Largier JL (2009b) Nearshore larval retention in a region of strong upwelling and recruitment limitation. Ecology 90: 3489-3502

> Pillar SC, Armstrong DA, Hutchings L (1989) Vertical migration, dispersal and transport of Euphausia lucens in the southern Benguela Current. Mar Ecol Prog Ser 53: 179-190

> Queiroga H, Blanton J (2004) Interactions between behaviour and physical forcing in the control of horizontal transport of decapod crustacean larvae. Adv Mar Biol 47: 107-214

Rosenfeld LK (1988) Diurnal period wind stress and current fluctuations over the continental shelf off northern California. J Geophys Res 93:2257-2276

Shanks AL (2009) Pelagic larval duration and dispersal distance revisited. Biol Bull 216:373-385

Shanks AL, Shearman RK (2009) Paradigm lost? Cross-shelf distributions of intertidal invertebrate larvae are unaffected by upwelling or downwelling. Mar Ecol Prog Ser 385:189-204

Sulkin SD (1975) The influence of light in the depth regulation of crab larvae. Biol Bull 148:333-343

Sulkin SD (1984) Behavioral basis of depth regulation in the larvae of brachyuran crabs. Mar Ecol Prog Ser 15:181-205

Tankersley RA, McKelvey LM, Forward RB Jr (1995) Responses of estuarine crab megalopae to pressure, salinity and light: implications for flood-tide transport. Mar Biol 122:391-400

Woodson CB, Webster DR, Weissburg MJ, Yen J (2007) Cue hierarchy and foraging in calanoid copepods: ecological implications of oceanographic structure. Mar Ecol Prog Ser 330:163-177

Young CM (1995) Behavior and locomotion during the dispersal phase of larval life. In: McEdward L (ed) Ecology of marine invertebrate larvae. CRC Press, Boca Raton, FL

> Zeng C, Naylor E (1996a) Endogenous tidal rhythms of vertical migration in field collected zoea-1 larvae of the shore crab Carcinus maenas: implications for ebb tide offshore dispersal. Mar Ecol Prog Ser 132:71-82

> Zeng C, Naylor E (1996b) Synchronization of endogenous tidal vertical migration rhythms in laboratory-hatched larvae of the crab Carcinus maenas. J Exp Mar Biol Ecol 198:269-289

Submitted: June 22, 2012; Accepted: October 30, 2012 Proofs received from author(s): February 9, 2013 